\begin{tabular}{|cc|}
\hline ETHENE & PROPENE \\
1,3-BUTADIENE & BENZENE \\
GASOLINE & COMBUSTION \\
COLD STARTS & FAST TRAFFIC \\
ANALYSIS & EXPOSURE \\
\hline
\end{tabular}

Open access accepted manuscript version of

Chemosphere 24 (1992) 135-140

\title{
Proportions of volatile hazardous hydrocarbons in vehicle-polluted urban air
}

\author{
Lars Löfgren and Göran Petersson \\ Department of Chemical Environmental Science, Chalmers University of Technology, \\ S-41296 Göteborg (Sweden)
}

Subsequent comparable studies:

$\underline{\text { Road tunnel }}$

$\underline{\text { Commuter buses }}$ 


\title{
PROPORTIONS OF VOLATILE HAZARDOUS HYDROCARBONS \\ IN VEHICLE-POLLUTED URBAN AIR
}

\author{
Lars Löfgren and Göran Petersson \\ Department of Chemical Environmental Science \\ Chalmers University of Technology \\ S-412 96 Göteborg, Sweden
}

\section{ABSTRACT}

Hydrocarbons of particular toxicological interest were determined in Scandinavian urban air as their fraction of total hydrocarbons except methane. Samples were taken on triple-layer adsorbent cartridges and the $\mathrm{C}_{2}-\mathrm{C}_{8}$ hydrocarbons were analyzed by gas chromatography on an $\mathrm{Al}_{2} \mathrm{O}_{3} / \mathrm{KCl}$ column.

The approximate ratios 10:4:1 were observed for ethene, propene and butadiene. The proportion of these combustion-derived alkenes was low for cold starts, and highest for fast traffic. The proportions of benzene and total aromatic hydrocarbons were typically as high as $7 \%$ and $50 \%$, respectively. Human exposure to the hydrocarbons is discussed.

\section{INTRODUCTION}

Exposure to volatile hydrocarbons in traffic-polluted air is presently the subject of increased attention and concern. Ethene is thought to constitute a major cancer risk via metabolic formation of its genotoxic epoxide (Törnqvist $e t$ al., 1988). Similar health hazards are attributed to other alkenes such as propene, butenes and the carcinogenic 1,3-butadiene, which were recently assessed in urban air (Löfgren and Petersson, 1991). The carcinogenic benzene and prominent alkylbenzenes are included in the large American TEAM exposure study (Hartwell et al., 1987).

Total hydrocarbons or a few prominent hydrocarbons are often monitored in urban air. The simultaneous assessment of the whole range of individual hydrocarbons is a much more difficult and laborious task (Dulson, 1978, Nelson $e t$ al., 1983, Zweidinger et al., 1988). The purpose of the present study was to determine representative proportions of selected vehicle-emitted hydrocarbons in Scandinavian urban air, thus facilitating exposure estimates for individual hydrocarbons of particular concern. 


\section{EXPERIMENTAL}

Field samples were taken on triple-layer adsorbent cartridges containing Tenax TA, Carbotrap and Carbosieve S-III. The accurately determined air volumes pumped through the cartridge were in the litre range. In the laboratory, the hydrocarbons were thermally desorbed into the cold trap of a gas chromatograph. The subsequent temperature-programmed analytical separation was effected by a $50 \mathrm{~m} \times 0.32 \mathrm{~mm}$ i.d. PLOT column (Chrompack) with $\mathrm{Al}_{2} \mathrm{O}_{3}$ treated with $5 \% \mathrm{KCl}$ as the stationary phase. The temperature sequence was $0-110^{\circ} \mathrm{C}\left(10^{\circ} \mathrm{C} \mathrm{min}-1\right), 110^{\circ} \mathrm{C}\left(14 \mathrm{~min}\right.$.), and $110-200^{\circ} \mathrm{C}\left(4^{\circ} \mathrm{C} \mathrm{min}^{-1}\right)$. For the detection by flame ionization, the same response factors were used for all hydrocarbons except for a $5 \%$ higher response for benzene. Further analytical data were given in a recent methodological report focussed on alkenes (Löfgren et al., 1991a).

Data were collected from 20 - 30 samples thought to reflect exposure in various traffic environments. The analytical quality of the results was controlled by duplicate samples and by analyzing samples, taken on Tenax cartridges, on a different system for thermal desorption and gas chromatography (Löfgren et al., 1991b). Careful comparisons of the chromatographic results then permitted the sorting out of non-representative samples and results of inadequate analytical quality.

\section{RESULTS AND DISCUSSION}

\section{Proportions of hydrocarbons}

The samples studied were classified into three groups reflecting different kinds of human exposure. These groups correspond to urban air in general and air polluted mainly by fast traffic or by cold start emissions. In Table 1, hydrocarbon concentration ratios are given for three samples selected as representative for these categories of urban exposure. Results are given for five hydrocarbons linked to particular health hazards. Other hydrocarbons are grouped according to structure. The composition is expressed as percentages of total hydrocarbons except methane. The chromatographic assessment is illustrated in Figure 1 for the sample corresponding to cold starts.

Ethene, propene and butadiene are combustion products, and were present in the approximate ratios 10:4:1 in virtually all samples of traffic-polluted air. Benzene is present in up to $5 \%$ by volume in petrol, and the ratio between benzene and methylbenzene (toluene) is approximately $1: 2.5$ in liquid petrol. This ratio is approached for air polluted by cold starts with large tailpipe emissions of unburnt petrol components. The formation of benzene as a combustion product changes the ratio in urban air, and particularly in the vicinity of fast traffic where ratios approaching 1:1.5 were observed. 
Table 1. Percentual composition of hydrocarbons in polluted air representing exposure to different traffic emissions.

\begin{tabular}{lccc}
\hline & Urban air $^{\mathrm{a}}$ & Fast traffic $^{\mathrm{b}}$ & Cold starts $^{\mathrm{c}}$ \\
\hline ethene & 4.9 & 5.7 & 2.8 \\
propene & 2.0 & 2.9 & 1.2 \\
1,3-butadiene & 0.5 & 0.7 & 0.3 \\
benzene & 6.3 & 7.4 & 6.6 \\
methylbenzene & 13.9 & 14.2 & 16.2 \\
butenes & 1.3 & 1.6 & 1.0 \\
pentenes & 1.1 & 1.1 & 1.4 \\
butanes & 11.6 & 9.3 & 7.6 \\
pentanes & 9.1 & 8.4 & 8.6 \\
alkynes $\left(\mathrm{C}_{2}-\mathrm{C}_{3}\right)$ & 4.1 & 4.3 & 2.4 \\
alkanes $\left(\mathrm{C}_{6}-\mathrm{C}_{8}\right)$ & 13.0 & 12.8 & 17.2 \\
alkylbenzenes $\left(\mathrm{C}_{8}\right)$ & 15.6 & 14.9 & 16.9 \\
alkylbenzenes $\left(\mathrm{C}_{9}-\mathrm{C}_{10}\right)$ & 13.0 & 12.3 & 14.0 \\
\hline
\end{tabular}

${ }^{\mathbf{a}}$ Near ( $5 \mathrm{~m}$ from) street intersection with traffic lights (at Vasa hospital) in Göteborg, 11/30 -89, $0^{\circ} \mathrm{C}$, inversion. ${ }^{\mathbf{b}}$ On suburban bridge (Mölndals Bro) above the E6 motorway (90 km/h), 11/17 -89, $10^{\circ} \mathrm{C}$. $\mathbf{C}_{\text {Inside garage exit }}$ (Landala) near cars leaving in the morning, $5 / 23-90,15^{\circ} \mathrm{C}$.

The results for butenes and pentenes are explained by their emission as unburnt petrol components and by the formation of butenes as combustion products (Löfgren and Petersson, 1991). The butanes and other $\mathrm{C}_{4}$ and $\mathrm{C}_{5}$ hydrocarbons are also emitted as petrol vapours (Berglund and Petersson, 1990), resulting in elevated fractions in urban air compared to auto exhaust. The content of volatile butanes is kept high in Scandinavian winter petrol, and the fraction of butanes in vehicle-polluted air was found to be considerably lower in the summer than in the winter. On the other hand, the fraction of petrol vapours, including butanes, is higher in hotter regions (Nelson et al., 1983). Ethyne (acetylene) and propyne are combustion products, whereas the $C_{6}-C_{8}$ alkanes and the $C_{8}-C_{10}$ arenes are emitted as unburnt petrol components. Complementary determinations of the $\mathrm{C}_{8}-\mathrm{C}_{10}$ arenes were made essentially in accordance with a recent comprehensive study of traffic-emitted volatile aromatic hydrocarbons (Löfgren $e t$ al., 1991b).

The high proportion of arenes observed for urban air is explained by the high content of aromatic hydrocarbons in European petrol. The octane number requirements for unleaded petrol have partly been met by a further increase of the arene content, which is now approximately $50 \%$ in Sweden. The observed 


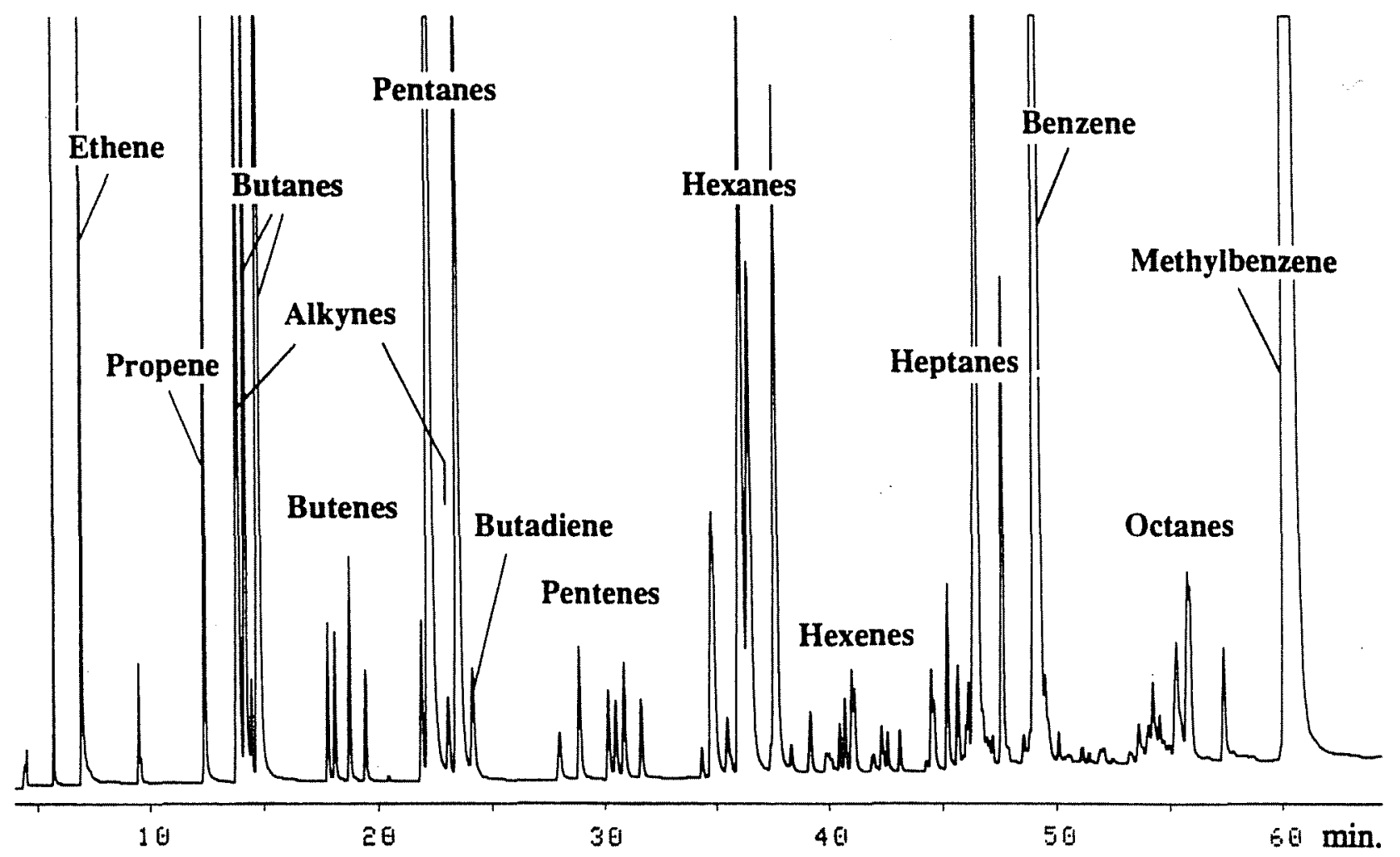

Figure 1. Gas chromatographic separation of hydrocarbons from a sample of air polluted by cold start emissions (cf. Table 1.)

proportions of hydrocarbons in urban air are close to those reported in an early German study (Dulson, 1978) with traffic based on petrol with a high arene content. In the US and other parts of the world, petrol contains less arenes and more alkanes. Combustion-derived alkenes are formed mainly from alkanes. As a result, hydrocarbon proportions in urban air tend to be lower for arenes and higher for $\mathrm{C}_{2}-\mathrm{C}_{4}$ alkenes in these regions (Nelson et al., 1983, Zweidinger et al., 1988).

Our results indicate an increased proportion of combustion-derived alkenes and benzene near to fluent and particularly near to fast traffic. A strong relationship between speed and tailpipe emissions of these hydrocarbons was recently demonstrated for conditions prevailing in Great Britain (Bailey et al., 1990). For ambient air, the effect of speed is partly masked by contributions from non-tailpipe emissions and cold starts. From Table 1, it is evident that unburnt petrol hydrocarbons predominate in cold start emissions. These emissions increase markedly at low ambient temperatures and are large for catalyst cars as well, during the few minutes before catalyst ignition (Stump et al., 1989). The combustion in catalyst cars appears to be more efficient for $\mathrm{C}_{2}-\mathrm{C}_{4}$ alkenes and less efficient for benzene, as compared with other hydrocarbons.

\section{Human exposure}

Illustrative absolute concentration levels are given in Table 2 for selected hydrocarbons of potential toxicological interest. The samples chosen include the 
Table 2. Concentrations $\left(\mu \mathrm{g} / \mathrm{m}^{3}\right)$ of selected hydrocarbons at locations representing exposure to air polluted by different traffic emissions.

\begin{tabular}{lccccc}
\hline & $\begin{array}{c}\text { Urban air } \\
\text { intersection }\end{array}$ & \multicolumn{2}{c}{$\begin{array}{c}\text { Fast Traffic } \\
\text { suburban }\end{array}$} & $\begin{array}{c}\text { Cold starts } \\
\text { garage }\end{array}$ \\
\hline ethene & 68 & 64 & 13 & 9.8 & 56 \\
propene & 28 & 26 & 6.5 & 3.8 & 24 \\
1,3-butadiene & 6.2 & 6.0 & 1.5 & 0.8 & 6.8 \\
hexane & 22 & 19 & 3.7 & 2.8 & 46 \\
benzene & 86 & 75 & 17 & 13 & 130 \\
methylbenzene & 190 & 170 & 31 & 25 & 330 \\
\hline
\end{tabular}

$\mathbf{a}$ Duplicate samples taken near intersection 11/30-89. Inversion. ${ }^{\mathbf{b}}$ Samples taken close to E6 (Mölndal) and E3 (Partille) $11 / 17-89$ and 2/6 -90. ${ }^{\mathbf{c}}$ Sample taken inside garage exit 5/23 -90 .

hydrocarbons of potential toxicological interest. The samples chosen include the three samples from Table 1 and represent the same three categories of human exposure. The urban air samples were taken during a winter inversion episode, with official warnings to the population for high air pollution levels in Göteborg. Corresponding normal levels are at least $50 \%$ lower, which should be observed when comparing with the more typical concentrations given for fast traffic and for garage cold starts. Throughout, the absolute concentrations are strongly dependent on traffic intensity, distance to vehicles, and ventilation parameters. The proportions between the hydrocarbons as given in Table 1 are therefore more widely applicable in exposure studies.

Most samples taken in urban environments corresponded closely in composition to the sample in Table 1, chosen to represent urban air in general. People exposed include urban motorists, pedestrians and cyclists near to motor traffic. Indoor concentrations due to traffic are normally lower because of the increased distance to the vehicles.

The samples representing fast traffic were taken at the roadside to find an average composition for the fleet of vehicles. The exposure of motorists inside their vehicles is high in dense traffic (Löfgren et al, 1991b) because the cars are in the mainstream of exhaust. Therefore, the exposure of urban motorists, car commuters and road travellers represent an important part of the population dose.

The exposure fraction caused by cold start emissions increases as the introduction of catalyst cars removes much of the emissions from driving with a warm engine. Catalyst cars made up $20-30 \%$ of the car fleet in Sweden by the time of the study. The large emissions from cold starts in the winter cause a considerable increase of hydrocarbon exposure, mainly to the motorists themselves. Garage cold starts give rise to particularly high exposure levels because of restricted indoor ventilation. 


\section{ACKNOWLEDGEMENTS}

The authors are grateful for support to studies of hydrocarbons in urban air from Vänersborg - Trollhätteregionens Luftvårdsförbund and from Göteborgs Miljö- och Hälsoskyddsförvaltning.

\section{REFERENCES}

Bailey J. C., Schmidl B. and Williams M. L. (1990). Speciated hydrocarbon emissions from vehicles operated over the normal speed range on the road. Atmos. Environ. 24 A, 43 - 52.

Berglund P.M. and Petersson G. (1990). Hazardous petrol hydrocarbons from refuelling with and without vapour recovery. Sci. Total Environ. 91, 49-57.

Dulson W. (1978). Organisch-chemische Fremdstoffe in atmosphärischer Luft. Schriftenreihe des Vereins für Wasser-, Boden- und Lufthygiene 47, 1 - 128. Hartwell T. D., Pellizzari E. D., Peritt R. L., Whitmore R. W., Zelon H. S. and Wallace L. (1987). Comparison of volatile organic levels between sites and seasons for the total assessment methodology (TEAM) study. Atmos. Environ. 21, 2413 - 2424.

Löfgren L., Berglund P. M., Nordlinder R., Petersson G. and Ramnäs O. (1991a). Selective assessment of $\mathrm{C}_{2}-\mathrm{C}_{6}$ alkenes in air by adsorption sampling and gas chromatography. Int. J. Environ. Anal. Chem., in press.

Löfgren L., Persson K., Strömvall A.-M. and Petersson G. (1991b). Exposure of commuters to volatile aromatic hydrocarbons of petrol exhaust. Sci. Total Environ., in press.

Löfgren L. and Petersson G. (1991). Butenes and butadiene in urban air. Sci. Total Environ., in press.

Nelson P. F., Quigley S. M. and Smith M. Y. (1983). Sources of atmospheric hydrocarbons in Sydney: A quantitative determination using a source reconciliation technique. Atmos. Environ. 17, 439 - 449.

Stump F., Tejada S., Ray W., Dropkin D., Black F., Crews W., Snow R., Siudak P., Davis C. O., Baker L. and Perry N. (1989). The influence of ambient temperature on tailpipe emissions from 1984 - 1987 model year light-duty gasoline motor vehicles. Atmos. Environ. 23, 307 - 320.

Törnqvist M., Kautiainen A., Gatz R. N. and Ehrenberg L. (1988). Hemoglobin adducts in animals exposed to gasoline and diesel exhausts. 1. Alkenes. J. Appl. Toxicol. $\underline{8}, 159-170$.

Zweidinger R. B., Sigsby J. E. Jr., Tejada S. B., Stump F. D., Dropkin D. L. and Ray W. D. (1988). Detailed hydrocarbon and aldehyde mobile source emissions from roadway studies. Environ. Sci. Technol. 22, 956 - 962. 